\title{
Pengaruh Mirror Therapy Terhadap Kekuatan Otot Pasien Stroke Non Hemoragik Di RSUD Kota Semarang
}

\author{
Fery Agusman $\mathrm{M}^{1}$, Evy Kusgiarti ${ }^{2}$ \\ 1. STIKes Karya Husada Semarang \\ 2. STIKes Karya Husada Semarang \\ E-mail:kusgiarti.via@gmail.com
}

\begin{abstract}
Abstrak
Sebesar $28,5 \%$ penderita stroke non hemoragik meninggal dunia dan sisanya mengalami kelumpuhan total atau sebagian. Hanya $15 \%$ saja yang dapat sembuh total dari serangan stroke atau kecacatan. Therapy Mirror merupakan terapi untuk pasien stroke dengan melibatkan sistem mirror neuron yang terdapat di daerah kortek serebri yang bermanfaat dalam penyembuhan motorik dari tangan dan gerak mulut.. Penelitian ini bertujuan untuk mengetahui Pengaruh Mirror Therapy terhadap kekuatan otot pasien Stroke Non Hemoragik di RSUD Kota Semarang Jenis penelitian kuantitatif, metode quasi experiment, Desain One Group Pretest-Posttest yaitu kelompok control dan kelompok intervensi. Jumlah sampel 10 pasien stroke non hemoragik. Teknik purposive sample. Uji normalitas data dengan Shapiro Wilks dan uji paired t test. Hasil Penelitian kekuatan otot sebelum dilakukan latihan Mirror Therapy pasien Stroke Non Hemoragik ratarata 1.600. sedangkan sesudah dilakukan latihan Mirror Therapy rata-rata 2.600. hasil uji normalitas $p$ value sebesar 0,000 dan $\mathrm{p}$ value kekuatan otot sesudah latihan mirror therapy adalah 0,030 $(>0,05)$. Kesimpulan : terdapat pengaruh yang signifikan latihan Mirror Therapy terhadap kekuatan otot pasien stroke non hemoragik. $\mathrm{t}$ hitung $=-2.428$ dengan $\mathrm{p}$ value $=0,015$

Saran : meningkatkan mutu pelayanan dengan cara memberikan pemahaman tentang pemberian latihan mirror therapy pada pasien stroke.
\end{abstract}

Kata Kunci: Kekuatan Otot;Mirror Therapy; Stroke Non Hemoragik

\section{Mirror Therapi's E ffect F or M uscle Strength On N on H emorrhagic's Stroke Patients At Semarang's H ospital}

\begin{abstract}
The 28.5\% non-hemorrhagic stroke patients died and the rest suffered total or partial paralysis. Only $15 \%$ that can be fully recovered from a stroke or disability. Mirror therapy is a therapy for stroke patients by involving the mirror neuron system of the region of the cerebral cortex is beneficial in treating the motor of the hand and mouth movement The research aim to know the Mirror Therapy Effect on muscle strength Non Haemorrhagic Stroke patients in hospitals Semarang. This research a quantitative method quasi experiment. This study was one group pretest-posttest namely the control group and the intervention group. Total sample of 10 respondents non-hemorrhagic stroke patients. Purposive sampling technique. The test data normality by Shapiro Wilks test and paired $t$ test. The result was muscle power before exercise Mirror Therapy Non Haemorrhagic Stroke patients an average of 1,600. whereas after doing the exercises Mirror Therapy on average 2,600. normality test results can be known $p$ value of 0.000 and $p$ value of muscle strength after exercise mirror therapy was $0.030(>0.05)$. Test results Pairet $t$ test, $t$ value of 2428 with a $p$ value of 0.015 , then there is a significant effect of exercise on muscle strength Mirror Therapy non-hemorrhagic stroke patients. These research suggest to improve the quality of service by providing an understanding of the provision mirror exercise therapy in stroke patients.
\end{abstract}

Keywords: mirror therapy; muscle strength; non-hemorrhagic stroke 


\section{Pendahuluan}

Penyakit stroke umumnya merupakan penyebab kematian nomor tiga, setelah penyakit jantung dan kanker. Namun, stroke paling banyak menyebabkan orang cacat pada kelompok usia di atas 45 tahun. Banyak penderitanya yang menjadi cacat, menjadi invalid, tidak mampu lagi mencari nafkah seperti sediakala, menjadi tergantung pada orang lain, dan tidak jarang menjadi beban keluarganya. Beban ini dapat berupa beban tenaga, beban perasaan, dan beban ekonomi (Guideline Stroke, 2011).

Prevelensi angka kejadian Stroke di RSUD Kota Semarang pada tahun 2015 didapatkan kasus stroke sebanyak 1.146 diantaranya sebanyak 590 kasus dengan stroke hemoragik dan 556 kasus dengan stroke non hemoragik. Selama ini Stroke telah menjadi masalah kesehatan yang mendunia dan semakin penting, dengan dua pertiga stroke sekarang terjadi di negara negara yang sedang berkembang.

Masalah yang sering dialami oleh penderita stroke dan yang paling ditakuti adalah gangguan gerak. Penderita mengalami kesulitan saat berjalan karena mengalami gangguan pada kekuatan otot, keseimbangan dan koordinasi gerak. Pasien stroke bukan merupakan kasus kelainan muskuloskeletal, tetapi kondisi stroke merupakan kelainan dari otak sebagai susunan saraf pusat yang mengontrol dan mencetuskan gerak dari sistem neuromuskuloskeletal. Secara klinis gejala yang sering muncul adalah hemiparesis.

Keadaan hemiparesis merupakan salah satu faktor yang menjadi penyebab hilangnya mekanisme refleks postural normal, seperti mengontrol siku untuk bergerak, mengontrol gerak kepala untuk keseimbangan, rotasi tubuh untuk gerak-gerak fungsional pada ekstremitas. Gerak fungsional merupakan gerak yang harus distimulasi secara berulang - ulang, supaya terjadi gerakan yang terkoordinasi secara disadari serta menjadi refleks secara otomatis berdasarkan ketrampilan aktifitas kehidupan sehari- sehari (AKS).

Pada pasien stroke 70 - $80 \%$ pasien mengalami hemiparesis (kelemahan otot pada salah satu sisi bagian tubuh) dengan $20 \%$ dapat mengalami peningkatan fungsi motorik dan sekitar 50\% mengalami gejala sisa berupa gangguan fungsi motorik / kelemahan otot pada anggota ekstrimitas bila tidak mendapatkan pilihan terapi yang baik dalam intervensi keperawatan maupun rehabilitasi pasca stroke (Akner, 2005).

Penatalaksanaan yang bisa dilakukan pada pasien stroke dengan kelemahan otot, selain 
terapi medikasi atau obat-obatan bisa dilakukan fisioterapi / latihan : latihan beban, keseimbangan, dan latihan ROM (Range Of Motion). Selain terapi rehabilitasi ROM yang sering dilakukan pada pasien stroke, terdapat alternatif terapi lainnya yang diterapkan pada pasien stroke untuk meningkatkan status fungsional pada sensori motorik, yaitu terapi latihan rentang gerak dengan menggunakan media cermin (mirror therapy).

Terapi cermin ini mudah dilakukan dan hanya membutuhkan latihan yang sangat singkat tanpa membebani pasien. Therapy Mirror merupakan terapi untuk pasien stroke dengan melibatkan sistem mirror neuron yang terdapat di daerah kortek serebri yang bermanfaat dalam penyembuhan motorik dari tangan dan gerak mulut. (Rizzolatti \& Arbib dalam Steven et al, 2010)

Sesuai penelitian yang pernah dilakukan Hendri (2013) menunjukkan bahwa hasil penelitian intervensi ROM terdapat perbedaan yang bermakna pada kekuatan otot ekstermitas bagian atas dan ekstermitas bagian bawah sebelum dan sesudah dilakukan latihan ROM.

Hasil Survey di RSUD Kota Semarang didapatkan bahwa selama 2 bulan terakhir (Agustus-September) ditahun 2016 diruang rawat inap didapatkan pasien stroke non hemoragik sejumlah 83 pasien, diantaranya perempuan sejumlah 35 dan pasien laki-laki sebanyak 48, rutin melakukan therapy kekuatan otot secara aktif maupun pasif. Status otot pasien mengalami kelemahan otot pada salah satu sisi bagian tubuh (hemiparesis) baik hemiparesis sisi kiri atau pun sisi kanan. Dengan renata kekuatan otot pada skala 2 ( $0-5$ ), hal ini disebabkan karena mekanisme hemiparesis yang terjadi umumnya pada pasien stroke.

Berdasarkan fenomena diatas, penulis tertarik untuk melakukan penelitian tentang pengaruh mirror theraphy terhadap kekuatan otot pasien stroke non hemoragik. Hasil penelitian ini diharapkan dapat lebih menyempurnakan pelayanan keperawatan yang telah ada saat ini.

\section{Metode Penelitian}

Jenis penelitian ini quasi eksperiment dengan rancangan One group pre-post test.. Penelitian ini dilakukan untuk mengetahui pengaruh Mirror Therapy pada pasien stroke Non Hemoragik.Populasi dalam penelitian ini diambil data dari Agustus - September 2016. Populasi dalam penelitian ini adalah semua penderita stroke non hemoragik yang dirawat di RSUD Kota Semarang sebanyak 83 penderita Stroke non hemoragik dalam rentang waktu dua bulan 
terakhir (agustus-september) 2016. Rata - rata populasi per bulan 41 penderita stroke non hemoragik. Teknik pengambilan sampel dilakukan dengan teknik Purposive sample. Instrumen penelitian menggunakan: prosedur Mirror Therapy, Skala Visual (VIS) yang mempunyai nilai 1-5 untuk menilai kemampuan pasien dalam membayangkan gerakan motorik melalui cermin, cermin dengan ukuran 25 x 20 inci, Skala MMT (Manual Muscle Testing) Semua uji analitik menggunakan $\mathrm{p}=0,05$.

\section{Hasil Penelitian}

Tabel 1 Distribusi frekuensi kekuatan otot sebelum dilakukan latihan Mirror Therapy pasien Stroke Non Hemoragik di RSUD Kota Semarang $(n=10)$

\begin{tabular}{ccccc}
\hline $\mathrm{N}$ & Mean & Std. Deviation & Min & $\max$ \\
\hline 10 & 1.600 & 0.516 & 1 & 2 \\
\hline
\end{tabular}

Tabel 1 diketahui bahwa pasien stroke non hemoragik di RSUD Kota Semarang mempunyai skor rata-rata 1.600 dengan Std. Deviation 0.516 dan skor terendah 1 tertinggi 2.

Tabel 2 Distribusi frekuensi kekuatan otot sesudah dilakukan latihan Mirror Therapy pasien Stroke Non Hemoragik di RSUD Kota Semarang $(n=10)$

\begin{tabular}{ccccc}
\hline $\mathrm{N}$ & Mean & Std. Deviation & Min & Max \\
\hline 10 & 2.600 & 1.074 & 1 & 4 \\
\hline
\end{tabular}

Tabel 2 diketahui bahwa pasien stroke non hemoragik di RSUD Kota Semarang mempunyai skor rata-rata 2.600 dengan Std. Deviation 1.074 dan skor terendah 1 tertinggi 4.

Tabel 3 Pengaruh Mirror Therapy terhadap kekuatan otot pasien Stroke Non Hemoragik di RSUD Kota Semarang

\begin{tabular}{ccc}
\hline Variabel & t hitung & P value \\
\hline Kekuatan otot pasien stroke non hemoragik & & \\
sebelum dan sesudah latihan mirror therapy & -2.428 & 0,015 \\
\hline
\end{tabular}

Hasil uji Pairet t test maka dapat diketahui nilai t hitung sebesar -2.428 dengan p value sebesar 0,015 maka dapat disimpulkan terdapat terdapat pengaruh yang signifikan latihan Mirror Therapy 
terhadap kekuatan otot pasien Stroke Non Hemoragik di RSUD Kota Semarang.

\section{Pembahasan}

Hasil penelitian menunjukkan bahwa pasien stroke non hemoragik di RSUD Kota Semarang mempunyai skor rata-rata 1.600 dengan Std. Deviation 0.516 dan skor terendah 1 tertinggi 2.. Hasil penelitian ini dapat diasumsikan bahwa sebagian besar pasien stroke mempunyai skor kekuatan otot yang rendah yaitu $0-2$ karena keterbatasan gerak akibat komplikasi stroke ini membuat pasien stroke non hemoragik memilih untuk membatasi aktivitas.

Keadaan hemiparesis merupakan salah satu faktor yang menjadi penyebab hilangnya mekanisme refleks postural normal, seperti mengontrol siku untuk bergerak,mengontrol gerak kepala untuk keseimbangan, rotasi tubuh untuk gerakgerak fungsional pada ekstremitas. Gerak fungsional merupakan gerak yang harus distimulasi secara berulang - ulang, supaya terjadi gerakan yang terkoordinasi secara disadari serta menjadi refleks secara otomatis berdasarkan ketrampilan aktifitas kehidupan sehari-sehari (AKS). Hemiparesis yang tidak mendapatkan penatalaksanaan yang optimal $30 \quad-\quad 60 \%$ pasien akan mengalami kehilangan penuh pada fungsi ekstremitas dalam waktu 6 bulan pasca stroke (Stoykov \& Corcos, 2009).

Hasil penelitian ini sesuai dengan penelitian Swierzewki (2010) yang menyebutkan bahwa Lebih dari $30 \%$ pasien stroke memerlukan bantuan dalam kehidupan sehari hari, sekitar $15 \%$ memerlukan fasilitas pelayanan perawatan (rumah jompo, pusat rehabilitasi), 20\% memerlukan bantuan berjalan (tongkat,wolker), 33\% menderita depresi.

Hasil penelitian menunjukkan bahwa pasien stroke non hemoragik di RSUD Kota Semarang mempunyai skor rata-rata 2.600 dengan Std. Deviation 1.074 dan skor terendah 1 tertinggi 4. Hasil penelitian ini menunjukkan bahwa dengan terapi dan latihan yang baik dan sesuai dengan kebutuhan pasien stroke maka kendala keterbatasan gerak dapat diatasi dengan baik.

Penatalaksanaan yang bisa dilakukan pada pasien stroke dengan kelemahan otot, selain terapi medikasi atau obat-obatan bisa dilakukan fisioterapi / latihan : latihan beban, keseimbangan, dan latihan ROM. Selain terapi rehabilitasi ROM yang sering dilakukan pada pasien stroke, terdapat alternatif terapi lainnya yang diterapkan pada pasien stroke untuk 
meningkatkan status fungsional pada sensori motorik, yaitu terapi latihan rentang gerak dengan menggunakan media cermin (mirror therapy).

Terapi cermin ini mudah dilakukan dan hanya membutuhkan latihan yang sangat singkat tanpa membebani pasien. Therapy Mirror merupakan terapi untuk pasien stroke dengan melibatkan sistem mirror neuron yang terdapat di daerah kortek serebri yang bermanfaat dalam penyembuhan motorik dari tangan dan gerak mulut. (Rizzolatti \& Arbib dalam Steven et al, 2010)

Prosedur umum terapi cermin adalah pasien duduk dan meletakkan cermin diantara kedua lengan / tungkai (Gambar 1) Selanjutnya perawat menginstruksikan kepada pasien agar lengan / tungkai yang sehat digerakkan fleksi dan ekstensi / keatas atau kebawah (Gambar 2). Saat lengan / tungkai yang sehat digerakkan, pasien dianjurkan untuk melihat cermin yang ada, kemudian pasien disarankan untuk merasakan bahwa lengan / tungkai yang mengalami kelemahan turut bergerak. Demikian diulang - ulang selama 10 menit dalam satu kali latihan (Mohammad Fathurochman, 2011:25).

Berdasarkan hasil uji Pairet t test maka dapat diketahui nilai t hitung sebesar 2.428 dengan $\mathrm{p}$ value sebesar 0,015 maka dapat disimpulkan terdapat terdapat pengaruh yang signifikan latihan Mirror Therapy terhadap kekuatan otot pasien Stroke Non Hemoragik di RSUD Kota Semarang.

Stroke non hemoragik didefinisikan sebagai sekumpulan tanda klinik yang berkembang oleh sebab vaskuler. Gejala ini berlangsung 24 jam atau lebih pada umumnya terjadi akibat kekurangan aliran darah ke otak, yang menyebabkan cacat atau kematian (Widjaja AC,2010).

Sekitar 85\%, Stroke non hemoragik terjadi akibat obstruksi atau bekuan di satu atau lebih arteri besar pada sirkulasi serebrum. Obstruksi dapat disebabkan oleh bekuan (trombus) yang terbentuk di dalam suatu pembuluh otak atau pembuluh atau organ distal. Trombus yang terlepas dapat menjadi embolus (Price SA \& Wilson LM,2006 : 1110-19).

Latihan mirror Therapy adalah bentuk rehabilitasi/ latihan yang mengandalkan dan melatih pembayangan/ imajinasi motorik pasien, dimana cermin akan memberikan stimulasi visual kepada otak (saraf motorik serebral yaitu ipsilateral atau kontralateral untuk pergerakan anggota tubuh yang hemiparesis) melalui observasi dari pergerakan tubuh yang akan ditiru seperti cermin oleh bagian tubuh yang mengalami gangguan (Wang, et al. 2013). 
Terapi cermin adalah suatu intervensi terapi baru yang difokuskan pada ekstermitas yang tidak mengalami gangguan. Menurut Bastian (2011, hlm. 2) pasien stroke yang sering mengalami gangguan bicara dan komunikasi dapat ditangani salah satunya dengan cara, latihan didepan cermin untuk latihan gerakan lidah, bibir, dan mengucapkan kata-kata. Terapi cermin merupakan intervensi terapi yang berfokus pada bergerak anggota tubuh utuh. Ini adalah bentuk citra yang digunakan untuk menyampaikan rangsangan visual ke otak melalui observasi dari bagian tubuh yang tidak mengalami gangguan untuk melakukan serangkaian gerakan.

Latihan gerak yang diberikan harus distimulasi untuk membuat gerak dan respon gerak sebaik dan senormal mungkin. Latihan pergerakan bagi penderita stroke non hemoragik merupakan prasyarat bagi tercapainya kemandirian pasien, karena latihan akan membantu secara berangsur-angsur fungsi tungkai dan lengan kembali atau mendekati normal, dan memberi kekuatan pada pasien tersebut untuk mengontrol kehidupannya.Latihan disesuaikan dengan kondisi pasien dan sasaran utama adalah kesadaran untuk melakukan gerakan yang dapat dikontrol denga baik, bukan pada besarnya gerakan. Pada penelitian yang dilakukan oleh Verles and Mulder (2007) bahwa sejumlah pasien melaporkan bahwa ilusi perasaan mereka bahwa lengan yang mengalami gangguan pergerakan dapat bergerak secara normal meskipun pola gerakan sebenarnya secara signifikan yang dihasilkan oleh ilusi pada lengan di cermin. Hipotesis ini menyatakan bahwa gerakan terbuka dan gerakan imajinasi pada dasarnya memiliki kesamaan dalam proses tejadinya gerakan.

Penelitian Anwar tentang terapi cermin dengan subjek pada posisi setengah duduk pada tempat tidur, subjek mengamati pantulan dari kaki yang non paretik sewaktu memfleksikan dan mengekstensikan pergelangan kaki pada kecepatan tertentu dibawah pengawasan terapi tanpa tambahan umpan balik secara verbal. Penelitian -penelitian sudah menunjukkan bahwa ilusi cermin mempunyai pengaruh dalam kemampuan pada pengukuran aktivitas otak (Anwar, 2007).

\section{Kesimpulan}

Hasil penelitian menunjukkan ada pengaruh yang signifikan latihan Mirror Therapy terhadap kekuatan otot pasien Stroke Non Hemoragik di RSUD Kota Semarang.. 


\section{Saran}

Perlu dilakukan penelitian lebih lanjut dengan frekuensi lebih sering dan waktu lebih lama dalam melakukan latihan Mirror therapy sehingga dapat meningkatkan kekuatan otot yang lebih baik dan efektif.

\section{Daftar Pustaka}

1. Junaidi, I. (2011). Stroke Waspadai Ancamannya Panduan Stroke Paling Lengkap.

Yogyakarta

2. Hendri Heriyanto (2015). Perbedaan kekuatan otot sebelum dan sesudah dilakukan latihan (mirror Therapi) pada pasien strok iskemik dengan hemiparesis di arsup Dr. Hasan Sadikin Bandung,Bandung 2015 (online) http://journal.respati.ac.id/index.php/ilmukeperawatan/article/view/324/265

3. RSUD Kota Semarang.Rekam Medik RSUD Kota Semarang 2016. Semarang 2016

4. Siti Rohmah. 2014. Efektifitas latihan ROM dengan latihan ROM Self terhadap kekuatan otot pasien Stroke di RSUD Tasik Malaya

5. Muhammadun A.S. 2010. Hidup Bersama Hipertensi. Yogyakarta: iN. Books

6. American Hearth Association. (2010) hearth deases and stroke statistic: our guide to current statistics and the suplement to our hearth and stroke .http//.americanhearth.org

7. Widjaja AC. Uji Diagnostik Pemeriksaan Kadar D-dimer Plasma Pada Diagnosis Stroke Iskemik. UNDIP. Semarang. 2010.

(online) http://eprints.undip.ac.id/24037/1/Andreas_Christian_Widjaja pdf

8. Wang, et al (2013). A comparison of neural mechanism in mirror therapy and movement observation therapy, Journal Rehabil Med

9. Anwar. (2007). Terapi cermin meningkatkan pemulihan motorik ekstremitas bawah dan fungsi motorik pasca stroke: Uji kontrol secara randomisasi. Semarang

10. Price SA \& Wilson LM. Patofisiologi. Konsep Klinis Proses-Proses Penyakit jilid 2. EGC. Jakarta. 2006: 1110-19. 